\title{
Isolation of aerobic, gliding, xylanolytic and laminarinolytic bacteria from acidic Sphagnum peatlands and emended description of Chitinophaga arvensicola Kämpfer et al. 2006
}

Correspondence Svetlana N. Dedysh dedysh@mail.ru

\author{
Timofei A. Pankratov, ${ }^{1}$ Irina S. Kulichevskaya, ${ }^{1}$ Werner Liesack $^{2}$ \\ and Svetlana N. Dedysh ${ }^{1}$
}
${ }^{1}$ S. N. Winogradsky Institute of Microbiology, Russian Academy of Sciences, Prospect 60-letya Octyabrya 7/2, Moscow 117312, Russia

${ }^{2}$ Max-Planck-Institut für terrestrische Mikrobiologie, D-35043 Marburg, Germany

\begin{abstract}
Four aerobic, heterotrophic, yellow-pigmented and flexirubin-producing bacterial strains with gliding motility were isolated from acidic Sphagnum-dominated wetlands of Northern Russia. These bacteria are capable of degrading xylan, laminarin and some other polysaccharides, but not cellulose, pectin or chitin. The four strains possess almost identical $16 \mathrm{~S}$ rRNA gene sequences and are most closely related (98.9-99.5\% sequence similarity) to the recently reclassified species of the phylum Bacteroidetes, Chitinophaga arvensicola Kämpfer et al. 2006, formerly known as [Cytophaga] arvensicola Oyaizu et al. 1983. However, the novel isolates from Sphagnum peat differed from C. arvensicola DSM $3695^{\top}$ in their ability to degrade xylan and starch, by greater tolerance of acidic $\mathrm{pH}$ and by their inability to reduce nitrate. An emended description of this species is proposed.
\end{abstract}

During the course of a study on biopolymer degradation in

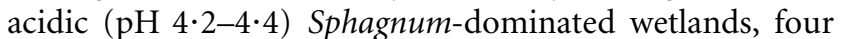
aerobic, heterotrophic, gliding and flexirubin-producing strains were isolated. The $16 \mathrm{~S}$ rRNA gene sequences of these isolates exhibited $96 \%$ similarity to the $16 \mathrm{~S}$ rRNA gene of the misclassified species of the phylum Bacteroidetes, [Cytophaga] arvensicola IAM $12650^{\mathrm{T}} \quad\left(=\mathrm{DSM} 3695^{\mathrm{T}}\right)$ (GenBank accession no. D12657). This species was recently transferred to the genus Chitinophaga and renamed as Chitinophaga arvensicola (Kämpfer et al., 2006). The species [Cytophaga] arvensicola was originally proposed by Oyaizu et al. (1983) to accommodate nine strains of rod-shaped, Gram-negative, non-motile, flexirubin-producing and succinoglycan-decomposing bacteria isolated from soil and the rhizosphere of cucumber plants. All of these strains were neutrophilic organisms and nothing was known about their capability to colonize acidic environments. The study of Kämpfer et al. (2006) contributed additional chemotaxonomic data for this species, but the phenotypic description remained identical to that given by Oyaizu et al. (1982).

The GenBank/EMBL/DDBJ accession numbers for the 16S rRNA gene sequence of Chitinophaga arvensicola DSM $3695^{\top}$ determined in this study and the 16S rRNA gene sequences of strains FX1, T2, T6 and Scyt01 are AM237311 and AM237312-AM237315, respectively.

A supplementary table comparing the cellular fatty acid contents of Chitinophaga arvensicola DSM $3695^{\top}$ and strain FX1 is available in IJSEM Online.
Thus, the goal of this study was to determine the taxonomy of our newly isolated strains from acidic wetlands in relation to the species Chitinophaga arvensicola.

Three strains, FX1, T2 and T6, were isolated from peat samples collected from the Sphagnum peat bog Bakchar, Tomsk region, West Siberia $\left(56^{\circ} 51^{\prime} \mathrm{N} 82^{\circ} 50^{\prime} \mathrm{E}\right)$. Aerobic cellulolytic communities were enriched using $120 \mathrm{ml}$ serum bottles containing strips of filter paper immersed in $30 \mathrm{ml}$ of five-fold diluted liquid mineral medium ST5 (Stanier, 1942), designated as DST5 medium. Cell suspensions of the resulting enrichments were spread-plated onto the surface of solid media for pure culture isolation. Two strains, FX1 and T2, were obtained using agar medium DST5 with the addition of either $0.1 \%(\mathrm{w} / \mathrm{v})$ starch or $1 \%(\mathrm{v} / \mathrm{v})$ peat extract, respectively. For the preparation of peat extract, $100 \mathrm{~g}$ peat was mixed with $50 \mathrm{ml}$ distilled water, homogenized and then centrifuged to sediment peat debris. A $5 \mathrm{ml}$ sample of this extract was added to $500 \mathrm{ml}$ of the base medium DST5. Strain T6 was isolated using DST5 medium with gellan gum (a polysaccharide from Alteromonas sp., Fluka) as a solidifying agent and a source of carbon. The fourth strain, Scyt01, was obtained from a peat sample collected from a Sphagnum-dominated peat bog near Syzran, Samara region $\left(53^{\circ} 09^{\prime} \mathrm{N} 48^{\circ} 27^{\prime} \mathrm{E}\right)$, by means of enrichment in liquid ten-fold diluted medium R2A (Difco) followed by plating onto a ten-fold diluted medium ST5, with agar as a solidifying agent and a source of carbon. 
All tests were performed with both the novel isolates and $C$. arvensicola DSM $3695^{\mathrm{T}}$ as a reference strain. Cell morphology and cell life-cycle were examined using batch cultures grown in liquid medium no. 67 recommended by the DSMZ (Deutsche Sammlung von Mikroorganismen und Zellkulturen, Braunschweig, Germany) for cultivation of C. arvensicola. Gliding motility was determined by direct microscopic examination of 1-2-day-old cultures. Flexirubin pigments were detected by suspending cells in $20 \%$ $\mathrm{KOH}$ (Fautz \& Reichenbach, 1980). The preparation of ultrathin sections was performed as described previously (Kulichevskaya et al., 2006). Growth of the novel strains under a variety of conditions, including temperatures of $2-37^{\circ} \mathrm{C}, \mathrm{pH} 4 \cdot 0-8 \cdot 0$ and $\mathrm{NaCl}$ concentrations of $0 \cdot 01-3.0 \%(\mathrm{w} / \mathrm{v})$, was examined using liquid medium DST5 with $0.04 \%(\mathrm{w} / \mathrm{v})$ glucose. The $\mathrm{OD}_{600}$ was measured in an Eppendorf BioPhotometer at 2-day intervals for 2 weeks. The range of potential growth substrates of the novel strains was examined using $0.04 \%(\mathrm{w} / \mathrm{v})$ concentrations of the respective carbon sources. The capability to degrade different biopolymers was examined by measuring the rate of $\mathrm{CO}_{2}$ production in tightly closed $120 \mathrm{ml}$ serum bottles containing $20 \mathrm{ml}$ liquid medium DST5 with $0.04 \%(\mathrm{w} / \mathrm{v})$ of the corresponding polymer substrate for 1 month at $20^{\circ} \mathrm{C}$. Control incubations were run in parallel under the same conditions, but without substrate. Cellular fatty acid analyses were performed by the DSMZ Identification Service. The DNA G $+C$ content of the strains was determined by thermal denaturation using a spectrophotometer (SP1800; Unicam) at a heating rate of $0 \cdot 5^{\circ} \mathrm{C} \mathrm{min}{ }^{-1}$. The DNA G $+\mathrm{C}$ mol\% value was calculated according to Owen et al. (1969). PCR-mediated amplification of the 16S rRNA gene was performed using primers Eub9f and Eub1492r and reaction conditions as described by Weisburg et al. (1991). The 16S rRNA gene amplicons were purified using QIAquick spin columns (Qiagen) and sequenced on an ABI Prism 377 DNA sequencer (PE Applied Biosystems). Phylogenetic analysis was carried out using the ARB software package (http://www.arb-home.de).

The novel isolates from Sphagnum peat formed flat, yellowpigmented, irregularly shaped colonies, which showed a spreading development on solid media. One strain, Scyt01, formed broad craters on the surface of agar media. The cells of these strains were Gram-negative rods, which underwent a cyclic shape change during the course of culture development. When plated onto a fresh solid medium, the isolates grew into long $(10-40 \mu \mathrm{m} \times 0 \cdot 4-0.5 \mu \mathrm{m})$ and agile thread cells (Fig. 1a). During this growth stage, gliding was observed in all of the strains, including C. arvensicola DSM $3695^{\mathrm{T}}$. This type of cell morphology was maintained for 1-2 days of growth. On ageing, long cells divided into several non-motile, shorter $(1 \cdot 5-5 \mu \mathrm{m} \times 0.5-0 \cdot 7 \mu \mathrm{m})$ cells, which were slightly fatter and darker in comparison with the thread cells (Fig. 1b). Ultrathin sections of the long cells taken before the division stage revealed the presence of multiple nucleoids (Fig. 1c). If cells from this growth stage were stained with DNA-specific dyes, several intensively
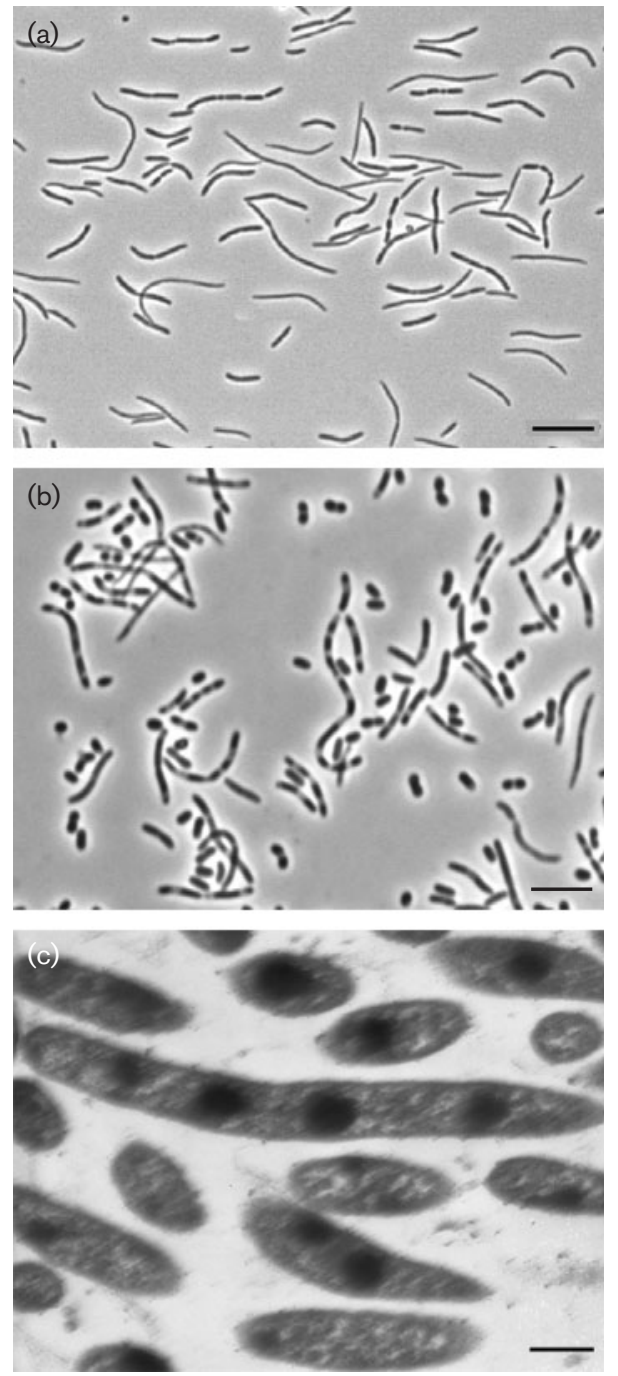

Fig. 1. Phase-contrast micrographs of cells of strain FX1 grown on DSMZ medium no. 67 for 1 day (a) and for 5 days (b). (c) Electron micrograph of an ultrathin section of cells from a 5-day-old culture of strain FX1. Bars, $5 \mu \mathrm{m}(\mathrm{a}, \mathrm{b})$ and $1 \cdot 0 \mu \mathrm{m}$ (c).

stained and regularly spaced dots became visible (data not shown). After division, the culture continued to grow with shorter cells. Old cultures consisted of short rods $(0 \cdot 7-2 \cdot 0 \times 0 \cdot 5-0 \cdot 7 \mu \mathrm{m})$.

Most phenotypic characteristics of strains FX1, T2, T6 and Scyt01 were similar to those of C. arvensicola DSM $3695^{\mathrm{T}}$ (Table 1). However, our novel isolates from Sphagnum peat were not capable of nitrate reduction and degraded a wider range of biopolymers. C. arvensicola DSM $3695^{\mathrm{T}}$ could hydrolyse only two polysaccharides, gellan gum and laminarin. All novel isolates from peat were capable of hydrolysing starch, laminarin and xylan. Strains FX1, T2 and T6 could also degrade gellan gum, while strain Scyt01 could degrade agar. None of the strains were capable of degrading cellulose, carboxymethylcellulose, pectin or chitin. 
Table 1. Phenotypic characteristics of Chitinophaga arvensicola DSM $3695^{\top}$ and novel isolates from Sphagnumdominated wetlands

Strains: 1, C. arvensicola DSM 3695 ${ }^{\mathrm{T}} ; 2$, FX1; 3, T6; 4, T2; 5, Scyt01. All strains were oxidase- and catalase-positive and ureasenegative. All strains were capable of gelatin liquefaction, but none of the strains produced indole or $\mathrm{H}_{2} \mathrm{~S}$. All strains produced acid from D-glucose, D-xylose, D-maltose, D-rhamnose and D-galactose. All of the strains were able to hydrolyse casein, laminarin and aesculin. None of the strains were able to hydrolyse cellulose, carboxymethylcellulose, chitin, pectin or Tweens 20,40 and 80 . + , Positive; -, negative: ND, not determined.

\begin{tabular}{|lccccc|}
\hline Characteristic & $\mathbf{1}$ & $\mathbf{2}$ & $\mathbf{3}$ & $\mathbf{4}$ & $\mathbf{5}$ \\
\hline Gliding motility & + & + & + & - & + \\
Flexirubin pigments & + & + & + & + & - \\
Acid from carbohydrates: & & & & & \\
$\quad$ D-Cellobiose & + & + & - & + & + \\
D-Sucrose & + & + & + & + & - \\
Hydrolysis of: & & & & & \\
Agar & - & - & - & - & + \\
Gellan gum & + & + & + & + & - \\
Starch & - & + & + & + & + \\
$\quad$ Xylan & - & + & + & + & + \\
Nitrate reduction & + & - & - & - & - \\
DNA G + C content (mol\%) & $44 \cdot 8^{*}$ & $46 \cdot 4$ & $\mathrm{ND}$ & $\mathrm{ND}$ & $\mathrm{ND}$ \\
\end{tabular}

${ }^{\star}$ Data from Oyaizu et al. (1982).

Compared with C. arvensicola DSM $3695^{\mathrm{T}}$, the novel isolates from Sphagnum peat had a greater tolerance of acidic $\mathrm{pH}$. They grew in the $\mathrm{pH}$ range $4 \cdot 5-8 \cdot 0$, with an optimum of
$\mathrm{pH} 6 \cdot 0-6 \cdot 5$. The temperature range for growth was $4-37^{\circ} \mathrm{C}$, with an optimum at $25-28^{\circ} \mathrm{C}$. Growth was completely inhibited at $\mathrm{NaCl}$ concentrations above $3.0 \%(\mathrm{w} / \mathrm{v})$.

The cellular fatty acid content of strain FX1 was very similar to that of C. arvensicola DSM $3695^{\mathrm{T}}$ (see Supplementary Table S1 in IJSEM Online). The major fatty acids were i15: $0,16: 1 \omega 5 c$ and $\mathrm{i} 17: 03-\mathrm{OH}$.

Since the earlier published sequence of the 16S rRNA gene from C. arvensicola DSM $3695^{\mathrm{T}}$ (GenBank accession no. D12657) was relatively short (1263 bp) and contained numerous ambiguous positions, we redetermined this sequence in our study. Comparison of the previously determined and newly determined sequences revealed a number of erroneous nucleotide position assignments in D12657. Thus, the sequence determined in the present study should be used to replace sequence D12657. Comparative sequence analysis of the 16S rRNA gene showed that novel strains FX1, T2, T6 and Scyt01 were very similar to each other (99.1-99.9\% sequence similarity) and to C. arvensicola DSM $3695^{\mathrm{T}}$ (98.9-99.5\% similarity) and belonged to the family 'Flexibacteraceae' of the phylum Bacteroidetes (Fig. 2). The $16 \mathrm{~S}$ rRNA gene sequence similarity values with other members of the genus Chitinophaga were 93 to $95 \%$.

The results of our study suggest that the four novel isolates from Sphagnum peat represent the same species as $C$. arvensicola Kämpfer et al. 2006. However, they differ from the type strain by the ability to degrade xylan, starch and some other polysaccharides, by greater tolerance of acidic $\mathrm{pH}$ and by the inability to reduce nitrate. Our data show that these bacteria are more widespread than previously thought and inhabit both soils and acidic wetlands.

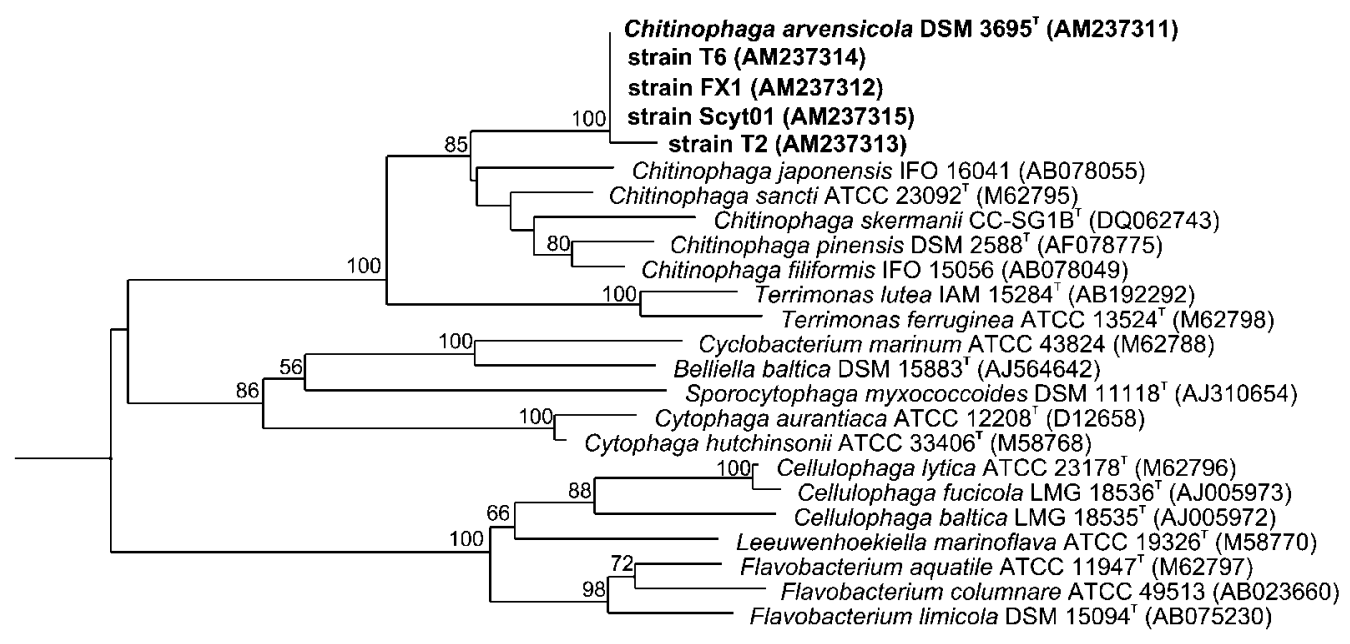

$0 \cdot 10$

Fig. 2. $16 \mathrm{~S}$ rRNA gene-based neighbour-joining tree showing the phylogenetic position of strains FX1, T2, T6 and Scyt01 in relation to members of the genus Chitinophaga and some other representative members of the phylum Bacteroidetes. Bootstrap values (1000 data resamplings) > 50\% are shown. Chlorobium limicola (Y10642) was used as an outgroup (not shown). Bar, $0 \cdot 1$ substitutions per nucleotide position. 


\section{Emended description of Chitinophaga arvensicola Kämpfer et al. 2006}

Basonym: Cytophaga arvensicola Oyaizu et al. 1983.

The description is the same as that given by Oyaizu et al. (1982) and Kämpfer et al. (2006) except for the following traits. Rod-shaped cells, motile by gliding. Cells undergo a cyclic shape change in the course of culture development. Young cultures contain long $(10-40 \mu \mathrm{m} \times 0 \cdot 4-0 \cdot 5 \mu \mathrm{m})$ and agile thread cells. On ageing, long cells divide into several non-motile shorter $(1 \cdot 5-5 \mu \mathrm{m} \times 0 \cdot 5-0 \cdot 7 \mu \mathrm{m})$ cells. Old cultures consist of short rods $(0 \cdot 7-2 \cdot 0 \times 0 \cdot 5-0 \cdot 7 \mu \mathrm{m})$. Colonies are yellow-pigmented, irregularly shaped, with non-entire edges and flat. Produces flexirubin. Chemoorganotrophic aerobe or microaerobe. Growth occurs at temperatures between 4 and $37^{\circ} \mathrm{C}$ and at $\mathrm{pH}$ values between 4.5 and $8 \cdot 0 . \mathrm{NaCl}$ inhibits growth at concentrations above $3 \%(\mathrm{w} / \mathrm{v})$. Major fatty acids are i15:0, 16:1 $\omega 5 c$, and i17:0 $3-\mathrm{OH}$. Nitrate reduction is variable. Utilizes mannitol, D-sucrose, D-cellobiose, D-rhamnose, D-galactose, inositol, D-xylose, D-glucose and D-maltose, but not sorbitol, acetate, citrate, D-arabinose or dulcitol. Hydrolyses casein, aesculin, gelatin, gellan gum and laminarin. Some strains are also capable of hydrolysing xylan, starch and agar. Does not hydrolyse cellulose, carboxymethylcellulose, pectin, chitin or Tweens 20, 40 and 80. Produces acid from D-glucose, D-xylose, D-cellobiose, D-maltose, D-sucrose, D-rhamnose and D-galactose. The DNA G + C content ranges from $42 \cdot 8$ to $46.4 \mathrm{~mol} \%$. Habitats are soils and acidic wetlands. The type strain is strain $\mathrm{M}^{\mathrm{T}}{ }^{\mathrm{T}} \quad\left(=\mathrm{IAM} \quad 12650^{\mathrm{T}}=\mathrm{DSM}\right.$ $3695^{\mathrm{T}}=$ ATCC $51264^{\mathrm{T}}=\mathrm{JCM} 2836^{\mathrm{T}}$ ), isolated from soil of Osaka Prefecture, Japan.

\section{Acknowledgements}

This research was supported by the 'Molecular and Cell Biology' Program of the Russian Academy of Sciences, the Russian Science Support Foundation and the Deutsche Forschungsgemeinschaft (436 RUS 113/543/0-3).

\section{References}

Fautz, E. \& Reichenbach, H. (1980). A simple test for flexirubin-type pigments. FEMS Microbiol Lett 8, 87-91.

Kämpfer, P., Young, C. C., Sridhar, K. R., Arun, A. B., Lai, W. A., Shen, F. T. \& Rekha, P. D. (2006). Transfer of [Flexibacter] sancti, [Flexibacter] filiformis, [Flexibacter] japonensis and [Cytophaga] arvensicola to the genus Chitinophaga and description of Chitinophaga skermanii sp. nov. Int J Syst Evol Microbiol 56, 2223-2228.

Kulichevskaya, I. S., Guzev, V. S., Gorlenko, V. M., Liesack, W. \& Dedysh, S. N. (2006). Rhodoblastus sphagnicola sp. nov., a novel acidophilic purple non-sulfur bacterium from Sphagnum peat bog. Int J Syst Evol Microbiol 56, 1397-1402.

Owen, R. J. \& Hill, L. R. \& Lapage S. P. (1969). Determination of base composition from melting profiles in dilute buffers. Biopolymers 7, 503-516.

Oyaizu, H., Komagata, K., Amemura, A. \& Harada, T. (1982). A succinoglycan-decomposing bacterium, Cytophaga arvensicola sp. nov. J Gen Appl Microbiol 28, 369-388.

Oyaizu, H., Komagata, K., Amemura, A. \& Harada, T. (1983). Cytophaga arvensicola sp. nov. In Validation of the Publication of New Names and New Combinations Previously Effectively Published Outside the IJSB, List no. 10. Int J Syst Bacteriol 33, 438-440.

Stanier, R. Y. (1942). The Cytophaga group: a contribution to the biology of myxobacteria. Bacteriol Rev 6, 143-196.

Weisburg, W. G., Barns, S. M., Pelletier, D. A. \& Lane, D. J. (1991). $16 \mathrm{~S}$ ribosomal DNA amplification for phylogenetic study. J Bacteriol 173, 697-703. 